\title{
Patriarchal Structure (Denying the Role of Women as Futile and Abstract) Violence against Women
}

\author{
Sajad Ahmad Khan \\ M.A (English), M.ed, Persuing: M.phill (English)
}

\begin{abstract}
From the womb of her mother till the leaving coffin to graveyard runs the story of the women with innumerable miserable plights including her feticide while being baby girl detected very before her birth in the very womb of her mother. Her birth make the parents sad and sorrowful. in society she is looked down with contempt, while passing through streets she Mets the lustful glances of male folk always and times molested, tortured \& even raped. The life of the women from all corners of the world including Middle-East India has now become the focus of the modern women writers as a theme of their works. It is because of women giving low status, her physically psychologically and sexually makes her reduce her mental capacity \& put her in the mouth of stress, depression, anxiety, worried \& even suicidal tendency.
\end{abstract}

\section{Introduction}

Women in all regions \& all communities had in one way or the other had been victimized with the lust of the man folk in the patriarchal male dominated society. Sexual violation, kidnapping, abduction, dowry deaths, murder, wife bettering are the violations which the women faces but regretfully female victims of violence have not been given most attention in the literature of social problems or in the literature of criminal violence aggression or injury committed by powerful (man) against less powerful (women) is not the violence, but it is the precisely the abuse of power.

In the multitude of context including schools, hospitals, homes, in workplaces she is not spared without being tortured physically \& psychologically in the present world the incidences of trafficking of young girls \& young women who are mainly sold into sexual slavery is altering their lives permentally each year.

Among of all the violations a women faces the most harsh and wicked stage comes when she is married either forcefully or early as in Afghanistan women faces variety of discrimination ranging from child marriage, forced marriage, polygamy \& even "Baad" a tribal custom of giving the forcible the hand of a widow or a girl to man from an opposing tribe to settle disputes \& end enmity.Moreover the treatment meted to her by in-laws \& by intimate partner Bride Burning or dowry death, divorce, sexual, psychological \& emotional violence inflicted by intimate partner is also wide spread. It is estimated that one in three are subject to some type of violence inflicted by partner over their life time.

Violence against women is a technical term used to collectively refer to violent acts that are primarily or exclusively committed against women .similar to a hate crime, this type of violence targets a specific group with the victim's gender as primary motive.

The united nation General assembly defines violence against women "as any act of gender-biased violence that results in, or is likely to result in, physical sexual or mental harm or suffering to a women, including threats of such acts, coercion or arbitrary deprivation of liberty whether occurring in public or in private life". The 1993 declaration on the elimination of violence against women noted that this violence perpetrated by assailants of either gender, family member and even the state itself $\left[{ }^{1}\right]$

\section{History Of Violence Against Women}

Violence against women has been accepted and even condoned throughout the history. More than 2000 years ago, Roman law gave a man a life and a death authority over his wife. In $18^{\text {th }}$ century, English common law gave a permission to discipline his wife and his children with a stick or whip no wider than his thumb. This "Rule of Thumb" prevailed in England and America until the late $19^{\text {th }}$ century. Many feminists claim violence against women is the result of deeply entrenched patriarchal culture that encourages and rewards male domination. They say in a patriarchal culture, men are more likely to use violence to keep the dominant position. While society claims to abhor violence, we often make heroes of men who are aggressive. In the culture of masculinity, heroes are often predicated on some kind of violent actions. the treatment model of masculinity encourages men to exude an aura of daring and aggression. 
Some historians believe that the history of violence against women is lied in the history being viewed as property and gender role assigned to be subservient to men and also other women $\left.{ }^{2}\right]$

The U.N declaration on the elimination of violence against women (1993) states that "violence against women is a manifestation of historically unequal power relations between men and women, which have led to domination over and discrimination against women by men and prevention of the full advancement of women and that violence against women is one of the crucial social mechanism by which women are forced into subordinate position compared with men" [A/RES/48/108. Declaration on the elimination of V.A.W UN] And [addressing Gender-Based violence: Advancing human rights UNFPA]. In 1870s courts in US stopped recognizing the common law principle that the husband had the right to physically chastise an errant wife $\left.{ }^{3}\right]$ In the U.K the traditional right of husband to inflict moderate corporal punishment on his wife in order to keep her "within the bounds of duty "was removed in $1891\left[{ }^{4}\right]$ The Quran verse An-Nisa 34 has been interpreted as supporting wife beating.

\section{Violence Inflicted upon Women}

\section{1) Female Infanticide:}

To ensure the birth of only male in the male-dominated society, the men who ruled after Prophet Muhammad have chosen to follow the tradition of Dark Ages (Female infanticide) rather than to follow Muhammad's words... "Prophet Muhammad scorned the practice of infanticide, common practice in his day of ridding the family of unwanted females. He in his very words ring with his concern at the possibility of abuse and indifference towards females; whoever hath a daughter and doth not bury her alive, or scold her, prefer his male children, to her, may God bring him into paradise $\left[{ }^{5}\right] \quad$ In this context I would like to court of female infanticide which as well presented the words of Tehmina in the novel, My Feudal Lord I come across on the p.28 as

"However, when my mother became pregnant, the convent nuns who looked after her told her that it was believed that the family practiced infanticide -the Nawab had no living female offspring, which was in those days , not uncommon among remote tribes. My mother left for Lahore to give birth at her own family home this was quite normal-the wife stayed away from her husband for forty days so that she could be well cared for and healthy enough to return to him ",

\section{2) Rape:}

Rape is forced ,unwanted sexual intercourse rape knows no borders as it effects female in every country in the world rape has been perpetrated on girls as young as 2 and against women as old as 90 . In context of war and conflict rape is prevalent, sometimes using guns and other objects in brutal force. In this context Vera Aderson in A Women like you narrates the story of a young girl of $16 \mathrm{yrs}$. Mandy who was raped when she was 8 yrs. Only by the acquaintance of her mother and and she feels her guilt and anger damaging her attitude towards boys and destroying her relationship with her mother.

\section{3) Sexual Assault:}

Sexual assault is an unwanted sexual contact that stops short of rape or attempted rape. Sexual assault takes many forms and is pervasive, occurring at work, in the home or within the community and should never be treated as anything less than a serious offence. Perpetrators may be family members or trusted members of the community, but this does not change the severity or danger of their action.

\section{4) Dowry Murder:}

Dowry murder is the practice in which bride's husband and /or in-laws kill her because her parents are unable to deliver the full amount or meet an increased demand for dowry. It has been reported that dowry demand have played and continue to play an important role in women being burned to death [ ${ }^{6]}$

\section{5)Domestic violence :}

Domestic violence refers to the physical and sexual assault in the home within the family or an intimate relationship. It intimate partner violence, marital rape, assault and battery and sexual abuse of children in the house hold; world wide $40-70 \%$ of all female murder victims are killed by an intimate partner.

\section{6)Early Marriage:}

Early marriage involves the the forced marriage of young girls, who is then extremely vulnerable to sexual violence. it refers to a forced marriage of a girll under the age of 18; girls as young As 6 or 7 have been victims. Early or forced marriage jeopardizes a girl's physical, emotional and spiritual well being. 


\section{7)Female genital cutting :}

Female genital cutting also refers as female circumscion or practice that are deeply rooted in traditional understanding of purity and chastity .in the context of rituals or rites of passage .Cutting operations which can cause irreparable pain and health problems, affect nearly 2 million women and girls each year .between 100 and 140 million women and girls in the world are estimated to have undergone female genital cutting. Religious leaders must defend the right for all women to live healthy and peaceful lives by condemning this cruel act, which is often based on misused religious principles and misunderstanding.

Female circumcision is the procedure involving partial or total removal of external female gentalia for religious, culture or other non-therapeutic reasons. Jean Sasson brings forth the puzzling project of circumcision in 'Princess' through the remarriage dialogue between kareema and sultana, when kareem naked sultana if she had been circumcised.in her innocence sultana asked the same question of circumscion at the family dinning table and for which her eldest sister,nura in the absence of her mother,was called upon to throw light on the subject of circumcision . sultana's sister , Nura told her," that she had been circumscised when she was about twelve years old "(p.59.Princess)

Jean sasson takes up the issue of female circumcision in 'Daughters of Arabia' when sultana listened to Fatima, a maid servant in Ciaro pleading with her daughter to cancel the planned ritual (circumcision) to spare her child greet pain and offering. Through the maid servant, jean sasson reveals the brutality of this inhuman act in Daughters Arabia:

“---- a women who had learned from respected physicians that the mutilations of girls (circumcision) was nothing more than a custom that had no basis or meaning in the modern life $\left[{ }^{7}\right]$

\section{8) Honor killing:}

Refers to the murder of women due to their perceived disgrace of family or community's 'honor' for things such as accused premarital sex, accused adultery, inappropriate behavior such as leaving the house without a male relative and even rape.preservation of honour is usually veiled in religious language , a dangerous manipulation of religion to justify an inexcusable practice. Women have been publicily stoned to death, burned alive and attacked with acid for such disgraces.

It is important to consider that stigma attached to raped women particularly an unmarried woman regardless of age, in Pakistan is as much entrenched in the socio-culture factors concerned with extra marital sex as it is in the religious context. Saha Suleri elaborates:

Objectifying honor in the person of woman, men posses honor, just as they posses gold and land - the three elements that are said to be the most sought after the commodities in Pakistan, at therefore to lie at the root of all conflicts. Logicallly it follows, women can't posses honor in the same way as men. They represent honor; they symbolize honor in the same way as men; they honor objectified into manipulable possession, symbolic or otherwise, women lose a sense of individuality in the eyes of community. Raping a woman robs a man of his most prized possession, his honor but it obliterates a women's whole being. Once a man's honor is violated, all he can do ,all he is expected to do ,all he should do is to seek revenge .as for the raped women, no one cares or dares to care ; she doesn't exist as if in the patriarchal male-dominated society.

alive, or scold her, prefer his male children, to her, may God bring him into paradise $\left[{ }^{5}\right] \quad$ In this context I would like to court of female infanticide which as well presented the words of Tehmina in the novel, My Feudal Lord I come across on the p.28 as

"However, when my mother became pregnant, the convent nuns who looked after her told her that it was believed that the family practiced infanticide -the Nawab had no living female offspring, which was in those days, not uncommon among remote tribes. My mother left for Lahore to give birth at her own family home this was quite normal-the wife stayed away from her husband for forty days so that she could be well cared for and healthy enough to return to him "

\section{References:}

[1]. United Nation Assembly decleration on elimination of V.A.W(1993)

[2]. U N Resolution 54/134 "international day for elimination of violence against women "un.org.]

[3]. Calvert R(1974)Criminal and Civil Liability in Husband/wife assaults]

[4]. R.V. Jackson(1891)I.Q.B 671 And Encyclopedia Britannica $11^{\text {th }}$ edit.1911.Article-Corporal punishment]

[5]. Jean sasson, princess: A True Story of Life Behind The Veils in Saudi Arabia. London: bantam books, 1993.p.28. (V.A.W in Jean Sasson's works by Vijay Mehta: ISSN: 2251-1571)]

[6]. Different forms of V.A.W. restoring dignity. Religious for peace international.org/learn different forms of V.A.W.

[7]. Jean Sasson, Daughters of Arabia. London :bantam books ,1994.p.255

[8]. Haeri shahla." The politics of Dishonor; rape and power in Pakistan] 
Patriarchal structure- (Denying the role of women as futile and abstract):

Literary patriarchy means "rule of father in a male dominated family". ${ }^{(1)}$ It is a social and ideological construct which considers men, who are the patriarchs, are superior to women. Sylvia Walby in Theorizing Patriarchy calls it 'a system of social structures and practices in which men dominate, oppress an exploit women' (2). Patriarchy is based system of power relations which are hierarchical an unequal where men control women's production, reproduction and sexuality. It imposes masculinity and feminity character stereotypes in society which strengthen the iniquitous power relations between men and women.

Patriarchal society is propagation of the ideology of fatherhood which restricts women's mobility and burdens them with responsibilities to nurture and rear children. The biological factor to bear children is linked to the social position of women's responsibilities of motherhood: nurturing, educating and raising children by devoting themselves to family. "Patriarchal ideas blur the distinction between sex and gender and assume that all socio-economic and political distinctions between men and women are rooted in biology or anatomy" (3). Gender like social class, caste, race or religion is a significant social cleavage and it is important to analyze it to understand social inequalities, oppressions and unequal relation between men and women.

\section{Structures of patriarchy}

The first lesson of patriarchy is learnt in the family ruled and dominated by the fatherhood. Man is considered the head of the family and controls women's sexuality, labour or production, reproduction and mobility. In a patriarchal family, the birth of a male child is preferred to that of a female. The former is considered as the inheritor of the family while the later is considered as the paraya dhan.

According to Gerda Lerner, 'family plays an important role in creating a hierarchical system as it not only mirrors the order in the state and educates its children but also creates and constantly reinforces that order'. ${ }^{(4)}$ Family is therefore important for socializing the next generation in patriarchal values. The boys learn to be dominating and aggressive; girls learn to be caring, loving, submissive and well-equipped with all the feminine virtues to please the families in general. These stereotypes of masculinity and feminity are not only social constructs, but they have also been internalized by both men and women. While the pressure to earn and look after the family is more on the man, the women are supposed to do the menial jobs and take care of their children and even other members of the family. It is because of these gender stereotypes that women are at disadvantage and are subjected to violence and other kinds of discrimination and injustice. Systematic deprivation and violence against women: rape, sexual harassment, sexual abuse, female foeticide, infanticide, sati, dowry deaths, wife beating, high level of female illiteracy, malnutrition, undernourishment and continued sense of insecurity keeps women bound to home, economically exploited, socially suppressed and politically passive ( Sylvia Walby, p.13).

Patriarchal construction of social practices are legitimized by the religious institutions, as the most of religious practices regard male authority as superior and the laws of conduct regarding family, marriage, divorce and inheritance are linked to patriarchal control over family biased against women; a person's legal identity with regard to marriage, divorce and inheritance are determined by his or her religion which laid down duties for men and women and their relationship. Most religions endorse patriarchal values and all major religions have been interpreted and controlled by men and upper caste and elite classes.

Tehmina Durrani, in her novel My Feudal Lord very aptly, realistically and graphically explores the life of women in Muslim culture where religious doctrines are used to circumscribe, exploit and oppress them. False and rigid interpretation of holy Quran renders women as subordinate and inferior to men. As the Quran states:

\footnotetext{
"Men are in charge of women, because Allah had made the

one of them to excel the other and because they spend

of their property (for support of women). so good women are obedient, guarding in secret that which Allah has guarded.

As for these (women) which ye rebellion, admonish them and

banish them to beds apart and scourge(beat) them.

Then if they obey you seek not a way against them.

Lo! Allah is the ever high exalted, great." (5)
}

Considering the nature of these laws it becomes apparent that the Quranic clause "men are in charge of women, because Allah hath made one them to excel the other" has been interpreted under the Sharia as Men having divinely sanctioned authority over women and thus thus the power of liberty to subjugate them as right of men as per the measures of Men and Religiosity.

"Mustafa, let suggestions pass, in the Feudal moral scheme, Islamic

law allow man to kill his unfaithful wife in a fit of passion,

but does not allow for premeditated vengeance.

So he simply divorced Safia and banished his offending younger 
brother to Britain" (6)

in the novel tehmina has clearly in the very beginning of the novel had made it clear how Feudal Lords have utilized islam as tool to subjugate women flock .

"in the areas that were later to become Pakistan, some feudal families

Utilized Islam as a weapon of control. The patriarchs were venerated as holy men who spoke with Allah. And, indeed at some earlier time many were pious and righteous. But gradually power passed to elder sons who were neither pious nor particularly moralyet were revered by illiterate peopleof the area and perceived as 'enovoys of Allah'. They had the authority to justify their every deed on the basis of their own, quite convenient, interpretation of the Quran. A feudal Lord was an absolute ruler who could justify any action"

$$
\text { ( My Feudal Lord p.39-40) }
$$

The Quran says,

"Do not be harsh with them (women) (sura Baqarah) even in divorce." Tehmina should have left Khar after the very first beating because he was violating a central example of Muhammad (pbuh): "The Prophet (pbuh) never raised his hand against a woman." [Sahih Hadith narrated by the best of women, 'Ayesha Siddiqa, R.A.].

Tehmina Durrani's book indicates that Khar did not hesitate to break any law of Islam if his sexual drive so urged him. In addition to adultery, he also carried out borderline incest (sex with his wife's sister, which is forbidden in the Qur'an.) At the general level of the masses, Pakistan is a puritanical society, where a man has to be careful to flirt with a woman. In many areas of Pakistan, such flirtation could have fatal results. But Khar, as a representative of the elites, could violate Islam with impunity.

In the context of woman's behavior, V. Geetha writes,

"----men wanting to be like women, or women wanting to do all that

men do, are seldom tolerated, especially if they presume their

desire and interest in every day terms." (7)

women/girls are kept barricaded in a strict discipline forced. They are segregated from social,religious and cultural life in the books of Themina ,be it her 'Blasphemy' or his autobiographical novel,' My Feudal Lord '.women are not permitted to meet and talk to the men other than their family members .

Tehmina narrates her state of mind in this set up as her personality failed to develop. Her mind becomes the sanctuary of secret thoughts of escaping such a house hold were she can't even sigh on her own will. Themina giving vent of such strict discipline in her house hold as-

"apart from my father, brother and a few close relatives, the

Men were alien creatures, and from my earliest moments I was was trained to avoid them. My childhood was encumbered to a lengthy list of don'ts, all designed to maintain an inviolate distance between myself and the masculine world: near wear make-up or nail polish. Do not look at boys.avoid modern girlfriends and avoid any girl who has an older brother. never visit a friend without a special permission and without your Nany . never pick up the telephone. Never go alone with driver.

Never stand around in the kitchen with the male servant

And yet clearly, a man was the only future available to

Pakistani girl. My role in life was to marry and to marry

Well. Mother had an ideal man in mind for each of us. Our husbands were to be the only males to whom we would be ever exposed. not surprisingly, they would exhibit a combination of eastern and western traits."

(My Feudal Lord p.28-29)

The Quran says,

"Do not be harsh with them (women) (sura Baqarah) even in divorce." 
Tehmina should have left Khar after the very first beating because he was violating a central example of Muhammad (pbuh): "The Prophet (pbuh) never raised his hand against a woman." [Sahih Hadith narrated by the best of women, 'Ayesha Siddiqa, R.A.].

Prophet Muhammad (pbuh) says

"The one who brought his two daughters well till marrying them off. On the Dooms Day I, (Prophet Muhammad pbuh) and the said person both will be in the heavens(Janat) similar way as the two fingers of the hand " (Muslim Sherief, a hadith narrated by Hazrat Anas Bine maalik ) 